\title{
Inducing High Temperature Shock at Onset of the Anthesis and Its Effect On Grain Quality of Wheat Cultivars
}

\author{
Rabia Goher ${ }^{1, a, *}$, Mohammad Akmal ${ }^{1, b}$ \\ ${ }^{I}$ Department of Agronomy, The University of Agriculture, Peshawar- Pakistan \\ *Corresponding author

A R T I C L E IN F O A B S T R A C T \\ Research Article \\ Uncertain heat shock by a rapid increase in temperature particularly at the critical growth stage \\ affects plant productivity. The study aimed to assess qualitative changes in wheat grains when plant \\ exposed to high temperature shock (HTS) at starting anthesis for limited durations (48, 72 and 96h). \\ Selected wheat cultivars (Pirsabak-2005, Pakhtunkhwa-2015, Pakistan-2013, DN-84, P-2, P-12 and \\ $\mathrm{P}-18$ ) were exposed to extending HTS effective from anthesis in the field covering plants within \\ plastic tents for a limited duration. The experiment was conducted in 2017-18 and 2018-19 at the \\ Research Farm, the University of Agriculture Peshawar, Pakistan in a randomized complete block \\ design, in three replications. Temperatures inside and outside plastic tents were manually noted. \\ Two years mean data showed significant effects of HTS on the wheat grain quality. Imposed HTS \\ for 48,72 and $96 \mathrm{~h}$ resulted in a reduction on grain amylose by 23,39 and $48 \%$ and wet gluten by \\ Keywords: \\ Amylose \\ Amylopectin \\ Gluten \\ Grain N-content \\ Heat-shock \\ 16,25 and $36 \%$, respectively when compared with the control (i.e. no HTS). Contrary to this, as \\ compared to the control treatment an increase noted in the grain amylopectin by $7,11 \& 17 \%$ and \\ in the grain $\mathrm{N}$-content by $13,28 \& 41 \%$ with imposing HTS extending to a duration of 48,72 and \\ $96 \mathrm{~h}$, respectively. The study concluded adverse effects of HTS at the anthesis stage on wheat grain \\ quality disturbing amylose and amylopectin ratios, which latter on brought changes in floor \\ structure and gluten elasticity. However, cultivar did differ to respond to the changes but have the \\ option to choose the best one.
}

\section{Introduction}

Wheat is an important staple food crop (Arystanbekkyze et al., 2019; Kumar et al., 2021). Its demand is higher in the developing countries due to high consumption as poor's food (Giraldo et al., 2019). Being a rich source of energy and carbohydrates, it provides components essential for the human health i.e. protein, vitamins, fibers and phyto-chemicals (FAOSTAT, 2018). Out of 7.34 billion populations on the earth, 1.83 billion lives in the South Asia and consume wheat as a major food item (FAOSTAT, 2015). Wheat crop is annually grown on around $40 \%$ of the total cropped area in Pakistan (FAO, 2013). Its production is reported around $2800 \mathrm{~kg} \mathrm{ha}^{-1}$, with $1800 \mathrm{~kg} \mathrm{ha}^{-1}$ in the province Khyber Pakhtunkhwa (MNSF\&R, 2019). China ranked first in wheat production with an annual production of $120.4 \mathrm{Mt}$ and is harvesting on average $9000 \mathrm{~kg} \mathrm{ha}^{-1}$ and other countries around 5000 to $6000 \mathrm{~kg} \mathrm{ha}^{-1}$ (Tao et al., 2014). In developing countries, releasing new cultivars is the more successful practice for higher production (Tomar et al., 2014).

Climate change is a new emerging threat to the existing wheat crop (Bajwa et al., 2020), which has affected both the yield and quality of wheat grains (Awan et al., 2017; Iftikhar et al., 2010). Yield and quality for good food are regulated by the prevailing climate of area during the crop growth and development (Abdullah et al., 2012; Parent et al., 2010). It has been observed that the climate of the world is changing since an increase in industrialization (IPCC, 2013). This increase has been documented to raise $1.5^{\circ} \mathrm{C}$ temperature from 2000 to 2015 on average and is expected to raise further $4^{\circ} \mathrm{C}$ by 2050 (Khan et al., 2013). In Pakistan, it was also observed that temperature of Khyber Pakhtunkhwa (KP) has raised by $1^{\circ} \mathrm{C}$ from 2005 to 2015 and is expected to rise $2^{\circ} \mathrm{C}$ by the year 2035 (Hanif and Ali, 2014). These changes in climate have shown an adverse effect on wheat production close to its maturity stage (Nutall et al., 2018). Temperature shocks at the critical stages of a crop growth e.g. anthesis in wheat significantly affect fertilization and grain development (Fan et al., 2018). The little shock of temperature fluctuation at the anthesis stage of the crops may harm productivity and grain quality (Farooq et al., 2011; Awan et al., 2017) by lowering down photosynthesis and oxidation of chloroplasts, which negatively affected grain quality (Farooq et al., 2011). 
Attention to extreme events, such as the high temperature shocks, is under consideration of the researchers in the changing climate (Teixeira et al., 2013) focusing grain quality (Liu et al., 2014). Crop responses to the high temperature shocks are reported differently (Nezhadahmadi et al., 2013).

Wheat being a major staple food crop is of more importance (e.g. food and feed) in Pakistan. This study aimed to quantify the effect of limited durations of HTS effective from the anthesis stage of the crop growth on selected wheat cultivars and quantify its effects addressing the grain quality parameters.

\section{Materials and Methods}

\section{Site Description}

Field experiments were conducted at Agronomy Research Farm of the University of Agriculture, Peshawar Pakistan, during winter 2017-18 and 2018-19. The location of the experimental site was at $34^{\circ} 1^{\prime} 13.50$ " $\mathrm{N}$ " and $71^{\circ}$ $28 ' 53.02$ "E", $350 \mathrm{~m}$ above sea level. Climate is subtropical, received $500-700 \mathrm{~mm}$ annual precipitation, with daily mean temperature varying from $24 \pm 6.24^{\circ} \mathrm{C}$ to $40.7 \pm 6.29^{\circ} \mathrm{C}$ during the wheat crop growth (i.e. Nov. to May). The soil of the experimental site is silt loam having $\mathrm{pH}>7.6$, organic matter less than $1 \%$. Sand $(18.13 \%)$ silt $(71.23 \%)$ and clay (10.64\%), and classified as Ustocrept based on USDA classification (Anonymous, 2007). The nutrient status of the soil is usually deficient with and $\mathrm{P}$ but $\mathrm{K}$ is moderate to sufficient (Perveen et al., 2010) Data regarding seasonal temperature (Max. and Min.) and rainfall of the crop growth period obtained from local Met. Department (PMD) are shown (Figure 1). The seasonal rainfall distribution for wheat crop is almost sufficient to meet the crop seasonal water requirements during the active growth period. However, temperature rise from February to April was a bit faster that terminated the crop vegetative growth to reproductive.

\section{Experimental Treatments and Design}

Experiments were conducted in a randomized complete block design (RCBD) in three replications. Treatments of the experiment were seven wheat cultivars (Pirsabak-2005, Pakhtunkhwa-2015, Pakistan-2013 and DN-84, P-2, P-12 and $\mathrm{P}-18$ ) exposed to three high temperature shock (HTS) by raising the temperature for three durations (i.e. 48,72 and $96 \mathrm{~h}$ ) effective from the crop anthesis stage of development. One control treatment with normal growth (i.e. no HTS) was also included. The selection of cultivars was based on their performance in field in the agro-climate as well as preference of growers for grain quality. Details of the cultivars status, year of release and preferences for cultivation are shown in Table 1 . Seeds were planted on Nov. 30, 2017 and Nov. 10, 2018 at the Agronomy Research Farm, the University of Agriculture Peshawar. Recommended seed rate $\left(100 \mathrm{~kg} \mathrm{ha}^{-1}\right)$ was used for all cultivars. Sowing was done in rows, using a hand drill, at $30 \mathrm{~cm}$ distances with 6 rows per experimental unit of $5 \mathrm{~m}$ length. The field was prepared as recommended for the wheat crop. Nutrients were added during seedbed preparation (N 120, P 80 and $\mathrm{K} 50 \mathrm{~kg} \mathrm{ha}^{-1}$ ) from urea, Single Super Phosphate and Murate of Potash sources, respectively. Nitrogen was applied in two equal splits at sowing and 50 days after sowing (DAS) with irrigation.

\section{High Temperature Shock (HTS) Imposition}

Five cultivars (i.e. Pirsabak-2005, Pakhtunkhwa-2015, Pakistan-2013, DN-84 and P-12) were uniform in anthesis and maturity, whereas, two (P-2 and P-18) were late in anthesis and maturity. Cultivars were subjected to artificial High temperature shock by raising growth temperature (HTS) effective from the anthesis stage of the crop growth. Two rows of the limited length in an experimental unit were protected through plastic tents developed on steel rods for rising inside temperature. An auto measuring temperature clock (Humidity/Clock HTC-01) was also installed within and outside the tents for measuring temperatures. On completion of HTS for defined durations, plastic tents were uncovered, and crop was allowed to grow normally. Control plots remained without HTS for the entire growth. Temperatures inside and outside the tents were recorded periodically and averaged for a mean reading. Mean of 10 , 15 , and 20 readings of the HTS for 48,72 and $96 \mathrm{~h}$, respectively were $3.08,4.04$ and $4.41^{\circ} \mathrm{C}$ in year 1 and 2.42 , 3.18 and $3.53^{\circ} \mathrm{C}$ in year 2 for early anthesis cultivars (Pirsabak-2005, Pukhtunkhuwa-2015, Pakistan-2013, DN $84, \&$ P-12) and 7.16, 7.23 and 7.37 for year 1 and 5.47, 5.91 and $6.25^{\circ} \mathrm{C}$ for the year 2 in late anthesis cultivars (P-2 and P-18).

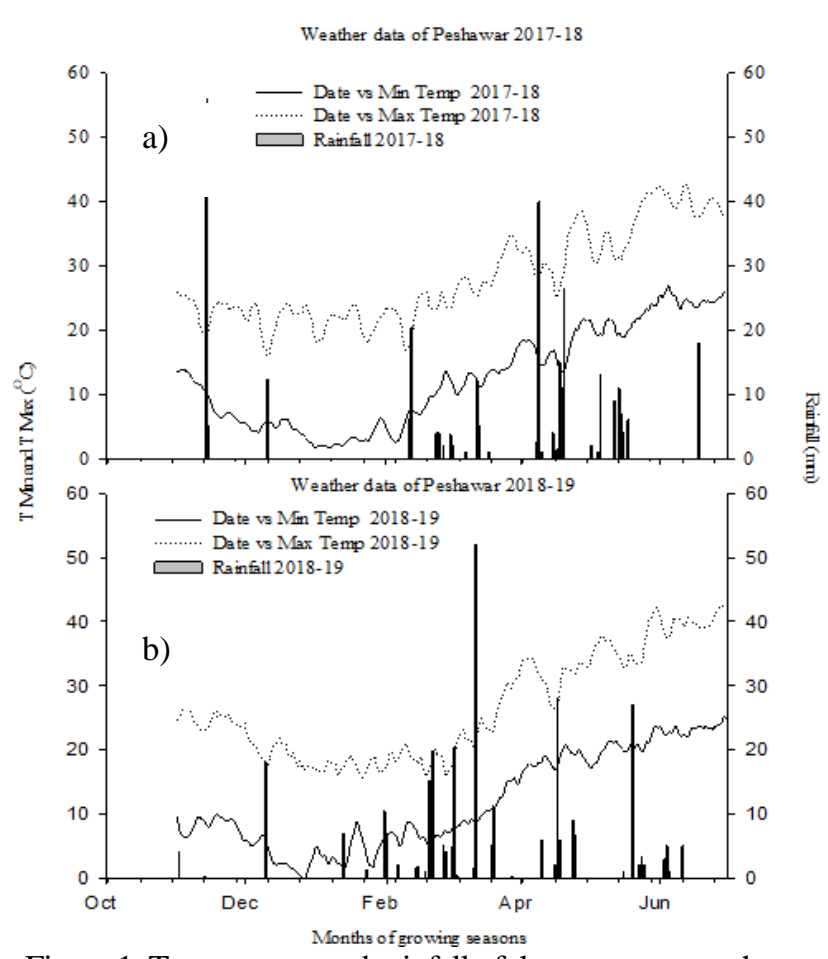

Figure 1. Temperature and rainfall of the crop seasons shown in separate windows for the experimental year (a) 2017-18 and

(b) 2018-19 with bars for rainfall (mm) and lines for temperature minimum $\left(\mathrm{T} \operatorname{Min}{ }^{\circ} \mathrm{C}\right)$ and maximum $\left(\mathrm{T} \operatorname{Max}{ }^{\circ} \mathrm{C}\right)$.

All other cultural operations e.g. irrigation, fungicide, weeding and nutrients etc. were kept uniform as recommended by the researcher in Cereal Crop Research Institute (CCRI) for the wheat crop. Harvesting was done manually at maturity on May 4, 2018 for early maturing and May 10, 2018 for late maturing cultivars in year 1 and May 5, 2019 and May 13, 2019 for early and late maturing cultivars, respectively in year 2 of the study. 
Table 1. Status of the cultivars used in the study.

\begin{tabular}{|c|c|c|c|c|}
\hline S.No & Cultivar's name & Year of release & Releasing Authority & Remarks \\
\hline 1 & Pakistan & 2013 & National Agric. Res. Center & Approved cultivar for \\
\hline & & & $\begin{array}{l}\text { (NARC), Islamabad \& FSC\&RD } \\
\text { Cereal Crops Res. Institute }\end{array}$ & $\begin{array}{l}\text { Pakistan } \\
\text { Approved cultivar for }\end{array}$ \\
\hline 2 & Pakhtunkhwa & 2015 & $\begin{array}{l}\text { (CCRI) Pirsabak Nowshera \& } \\
\text { Provincial Seed Council (PSC) }\end{array}$ & $\begin{array}{l}\text { Khyber Pakhtunkhwa rain- } \\
\text { fed \& irrigated areas }\end{array}$ \\
\hline 3 & Pirsabak & 2005 & & - do- \\
\hline 4 & DN-84 & 2017 & $\begin{array}{l}\text { Agric. Res. Institute (ARI), Ratta } \\
\text { Kulachi, D.I. Khan \&PSC }\end{array}$ & $\begin{array}{l}\text { Approved for D.I. Khan \& } \\
\text { rainfed area }\end{array}$ \\
\hline 5 & P-2 & - & $\begin{array}{l}\text { Facultative Line from Turkey } \\
\text { under Res. at ARS Chitral }\end{array}$ & $\begin{array}{l}\text { Candidate line for late } \\
\text { maturity }\end{array}$ \\
\hline 6 & P-12 & - & $\begin{array}{l}\text { Facultative Line from Turkey } \\
\text { under Res. at ARS Chitral }\end{array}$ & -do- \\
\hline 7 & P-18 & - & $\begin{array}{l}\text { Facultative Line from Turkey } \\
\text { under Res. at ARS Chitral }\end{array}$ & -do- \\
\hline
\end{tabular}

\section{Sampling and Measurements}

Sample of 10 spikes was collected from each experimental unit at the maturity stage of the crop and stored in labeled bags. Spikes were properly dried in a forced circulating hot air oven $\left(70^{\circ} \mathrm{C}\right)$ for three days and threshed. Grains were ground by passing through a $2 \mathrm{~mm}$ sieve on a lab grinding mill (Cyclone Mill Twister, 50/60 $\mathrm{Hz}, \mathrm{UK})$. Ground samples were preserved in labeled bags for further lab analysis.

Calorimetric iodine method (Juliano, 1971) was used for amylose and amylopectin (\%) estimation in wheat grain. Briefly, the ground sample $(100 \mathrm{mg})$ was collected in a tube, added with $1.0 \mathrm{ml}(95 \%)$ ethanol and $9 \mathrm{ml} \mathrm{NaOH}$ (1M). To gelatinize the starch, a tube was kept for $20 \mathrm{~min}$ in a water-bath. Boiled mixture was transferred to a flask and distilled water added to a final volume of $100 \mathrm{ml}$, and stationed for $23 \mathrm{~h}$ at room temperature. For error correction blank (without sample) was also prepared. After thorough stirring, $5 \mathrm{ml}$ solution was pipetted in a $100 \mathrm{ml}$ flask, added with $1 \mathrm{ml}$ of glacial acetic acid $(1 \mathrm{M})$ and $2 \mathrm{ml}$ iodine solution, adjusted $900 \mathrm{ml}$ volume with distilled water. The sample was thoroughly mixed and kept for 20 mins to develop dark blue color. Spectrophotometer was calibrated by running blank at $620 \mathrm{~nm}$ spectrum and samples were run on the same wavelength. Value of absorbance was converted to amylose content using a standard calibration curve developed for pure potato amylose (Figure 2).

\section{Amylose Curve}

A $12.5 \mathrm{mg}$ amylose and amylopectin took in separate tubes, added with $5 \mathrm{ml}(45 \%)$ per chloric acid and completely dissolved. Bring final volume to $50 \mathrm{ml}$ adding distilled water. Amylose stock $(6.25 \mathrm{ml})$ was taken from the $50 \mathrm{ml}$ solution, added with $18.75 \mathrm{ml}$ ultra-pure water making $6.25 \mathrm{mg} \mathrm{ml}^{-1}$ amylose solution, the repeated procedure for the amylopectin solution. Using this stock solutions standard solution of amylose and amylopectin were prepared $(0,10,20,30,40,50$ and $60 \%)$ to the final volume of $5 \mathrm{ml}$ for the standard curve. Transfer $40 \mu \mathrm{l}$ of each standard mixture to a micro-titer plate. Add with a $50 \mu \mathrm{l}$ of iodine solution $\left(2 \mathrm{~g} \mathrm{KI}+1 \mathrm{~g} \mathrm{I}_{2}\right.$ in $900 \mathrm{ml}$ of ultrapure water) and mixed each sample including blank (perchloric acid) by pipetting. Read absorbance at $620 \mathrm{~nm}$ immediately at spectrophotometer and calculate amylose ratio for the concentrations and developed the standard calibration curve using these concentrations (Figure 2).

\section{Grain Wet Gluten Content}

To determine seed gluten (\%), the hand wash method was used (AACC, 2004). From seeds of the ground sample $(20 \mathrm{~g})$ were taken and added with $14 \mathrm{ml}$ water to form a wet dough. After about $1 \mathrm{~h}$ dough was kept untouched, all soluble matters and starches were removed by washing in flowing water in a plastic tub. The resultant gluten-ball was kept in a tarred, flat-bottomed dish and weighed as wet gluten. For estimation of dry gluten, the gluten-ball was dried in a forced air circulating oven at $100^{\circ} \mathrm{C}$. Gluten $(\%)$ was determined as a ratio of glutted boll and sample weight, expressed in percentage.

\section{Grain N-Content}

Grain N-content (\%) was measured on grounds samples from selected spikes in each treatment. Kjelflex-K360 (Buchi, Switzerland) was used for N-determination following the protocol of Kjeldahl (Jones, 1991). Briefly, $0.2 \mathrm{~g}$ sample along with $1.3 \mathrm{~g}$ digestion mixture $\left(20 \mathrm{~g} \mathrm{CuSO}_{4}\right.$ $\left.+100 \mathrm{~g} \mathrm{~K} \mathrm{~K}_{2} \mathrm{SO}_{4}+0.2 \mathrm{~g} \mathrm{Se}\right)$ was digested with $3 \mathrm{ml}$ concentrated $\mathrm{H}_{2} \mathrm{SO}_{4}$ in digestion tube on digestion assembly till clearness of the sample and changing the colors to light green. The digest was filtered and distilled water was added to make volume $100 \mathrm{ml}$. $100 \mathrm{ml}$ solution added to sample tube of Kjelfelx-K360 and distilled with $40 \% \mathrm{NaOH}$ (prepared by adding $400 \mathrm{~g}$ of $\mathrm{NaOH}$ in $1 \mathrm{~L}$ of distilled water), collected in receiving flask having $4 \%$ $\mathrm{H}_{3} \mathrm{BO}_{3}$ (prepared by adding $40 \mathrm{~g}$ of $\mathrm{H}_{3} \mathrm{BO}_{3}$ in $1 \mathrm{~L}$ of distilled water), and titrated against $0.1 \mathrm{~N} \mathrm{HCL}(100 \mathrm{ml}$ of $1 \mathrm{~N}$ standard ampule added to $1 \mathrm{~L}$ distilled water) with 877 titrino plus. The reading for total $\mathrm{N}$ in a sample was adjusted with blanks and recorded. For crude protein, Ncontent multiplied with 6.25 .

Statistical analysis of data collected during the study was statistically analyzed as per procedure explained by Fishers Analysis of Variance Technique using Randomized Completely Block Design (RCBD) on the computer software "Statistix". Means found significant were separated using the least significant difference (LSD) test at probably 5\% (Steel et al., 1997). 


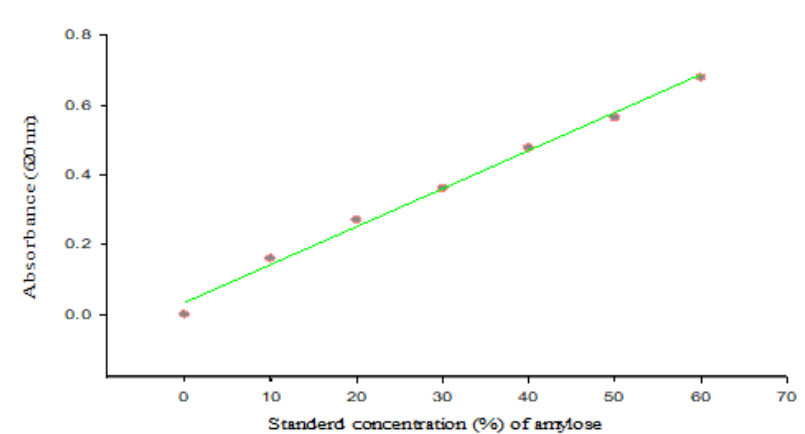

Figure 2. Amylose standard curve developed for amylose contents (\%) of wheat grains solid dot shows actual value against the regressed line

\section{Results and Discussion}

\section{Grain Amylose Content (\%)}

Among the qualitative characters, grain amylose content is most important to study, which were found significant $(\mathrm{P}<0.05)$ for given treatments (Table 2$)$. The high temperature shock (HTS) imposed on wheat cultivars at the anthesis stage showed significant changes in the grain amylose content. Higher grain amylose content was noticed for cultivar (C) Pakhtunkhwa-2015, followed by Pakistan-2013, P-12 the lowest was noted in P-2. Differences in amylose content were found among cultivars due to their seed sizes, shapes and structures of the outer layers that are strongly affected and varied with HTS during development (Cheng et al., 2000). Furthermore, magnitudes of changes (pitting and fissures) on the grain surface depend on the acuteness and duration of the HTS faced by grains during their growth and development (Balla et al., 2018). Liu et al. (2011) reported that HTS causes variation in starch granule (i.e. structure, shape and size) which depends on the index and duration of stress. Unexpected changes were observed in starch granule "A", when a stress was imposed at the anthesis stage to wheat (Hurkman et al., 2003). Nonetheless, "A" granules increases in response to the " $\mathrm{B}$ " granules under increasing HTS and hence their ratio disturbed, which caused the difference in grains amylose content of different wheat cultivars under the same HTS (Liu et al., 2011) leading to the poor texture of final product (food and nonfood) due to reduction in the viscosity of starch (Soh et al., 2006). Amylose content decreased a in linear fashion with increasing HTS from 48 to 72 and thereafter to $96 \mathrm{~h}$ for all cultivars. Increasing HTS has adversely affected the performance of starch synthesizing enzymes i.e. AGPase and soluble starch synthase, which could be the solid reason for the reduction in the amylose contents in wheat grain (Hurkman et al., 2003). Higher amylose was observed in the $2^{\text {nd }}$ year $(Y)$, which could be due to differences in temperature for HTS as already seen in the Figure 1.

Table 2. Grain amylose and amylopectin (\%) of selected wheat cultivars affected with imposing high temperature shock (HTS) with raising temperature effective from the anthesis stage of growth.

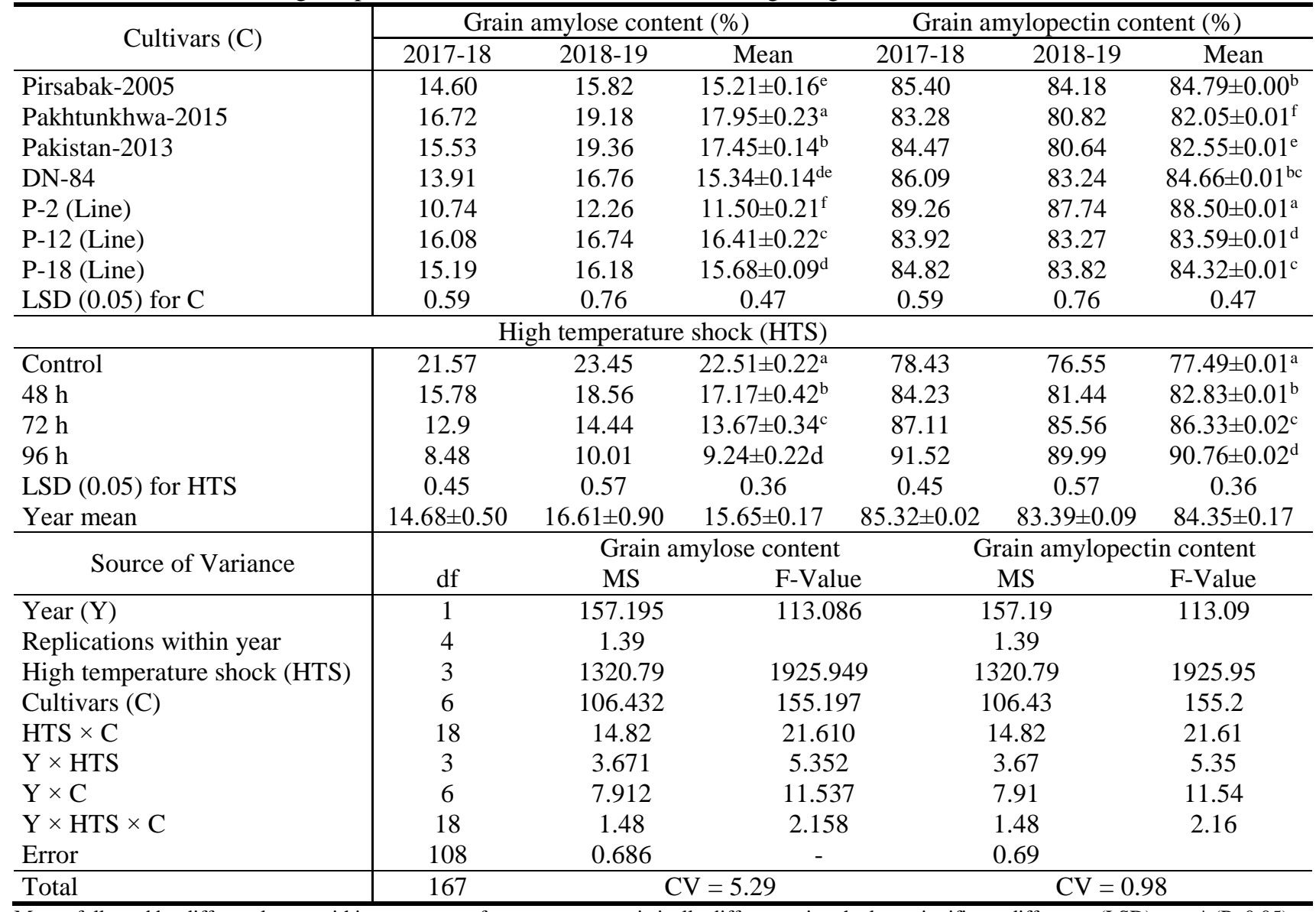

Means followed by different letters within a category of treatment are statistically different using the least significant difference (LSD) test; $*(\mathrm{P}<0.05)$, $* *(0.01)$ and NS == Non-significant. 
The interaction $(\mathrm{HTS} \times \mathrm{Y})$ also exhibited higher amylose in control in year 2 (Figure 3a), which was due to changes in the mean daily temperatures in the crop growing season. Literature also confirmed that as compared to normal conditions, crops exposed to HTS at anthesis showed lower starch content (Liu et al., 2011). The temperature at the crop anthesis stage was higher than $30^{\circ} \mathrm{C}$ and hence has shown marked differences in amylose content by extending the HTS duration. Treatment interaction $(\mathrm{C} \times \mathrm{HTS})$ also exhibited a stable reduction in amylose content of cultivars exposed to HTS, but with varying rates (Figure 3b). Pakistan-2013 showed relative resistance to HTS for decreasing the amylose content. Sangu (2018) reported that HTS at the post-anthesis stage of the wheat crop varies the starch granules and hence reflects changes in the amyloplast number in grains. Hawker and Jenner, (1993) confirmed that starch synthase was reduced by exposing spike to HTS for single day. It is, therefore, obvious if the HTS duration is extended, then a significant change in amylose content is supposed to be expected in wheat grains. Interaction $(\mathrm{C} \times \mathrm{Y})$ showed significantly higher amylose for year 2 in all cultivars with a marked increase in Pakhtunkhwa-2015, Pakistan-2013 and $\mathrm{DN}-84$ (Figure $3 \mathrm{c})$. Interaction $(\mathrm{C} \times \mathrm{HTS} \times \mathrm{Y})$ also showed a significant reduction in amylose content by increasing HTS in both years (Figure 3d). Pakhtunkhwa2015 and Pakistan-2013 exhibited relative resistance to HTS and P-2 susceptibility. Similar findings were also reported by earlier researchers (Beckles and Thitisaksakul, 2014).
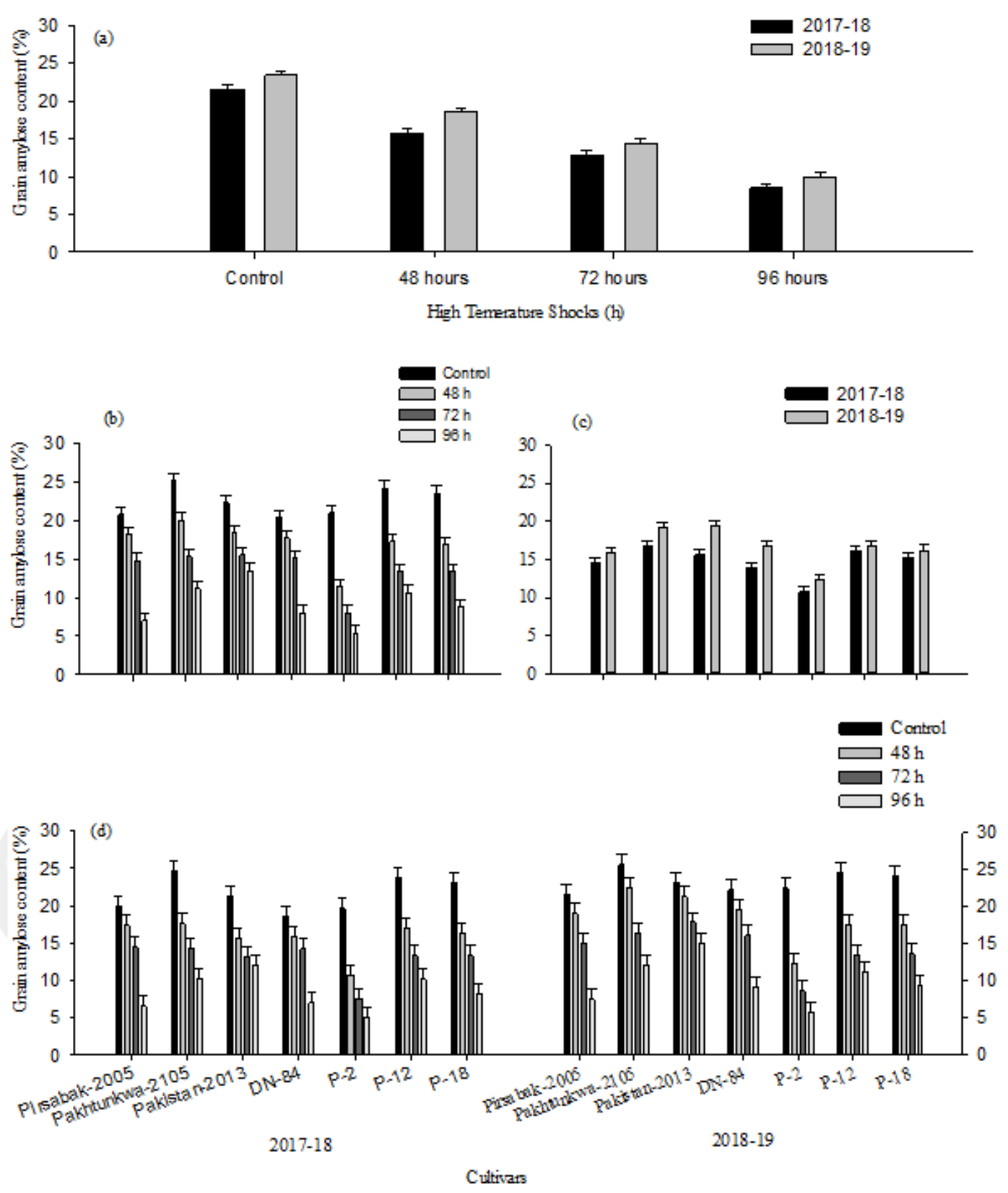

Figure 3. Interaction of (a) high temperature shocks $\times$ year, (b) cultivars $\times$ heat shock, (c) cultivars $\times$ year, and (d) cultivars $\times$ high temperature shocks $\times$ year effects on wheat grain amylose content $(\%)$ of the selected cultivars exposed to high temperature shocks at anthesis. LSD values of the mean are shown in vertical bars. 


\section{Grain Amylopectin Content}

Amylopectin content in wheat grains was found significant $(\mathrm{P}<0.05)$ for cultivars, HTS their interactions (Table 2). Two years' averages, revealed greater $(\mathrm{P}<0.05)$ amylopectin in wheat cultivar P-2, followed by Pirasbak2005, which was statistically similar with DN-84 while, the lowest in Pakistan-2013. Grain undergoes HTS during growth shows variation in compositions of starch granules (e.g. differences in structure, shape and size) as compared to normal conditions of growth (Zhang et al., 2006). The ellipsoidal shape and fissures appearance of the grain has shown variation to HTS with differences in the different cultivars. The changes observed in amylopectin might be due to changes in starch composition, concentration and viscosity, which have caused changes in the amylopectin content of cultivars (Schirmer et al., 2013). Amylopectin increased with increasing HTS. Increasing HTS durations brought a difference in the amount of total starch in wheat grains and ratios of amylose to amylopectin. Branlard et al. (2015) reported that the starch accumulation severely affected in developing grains under HTS at the anthesis stage due to changes in the distribution starch granule sizes. In starch amylose and amylopectin are the two major classes of polymer consist of straight and branch chained molecules. The ratio of amylose to amylopectin increases under HTS $\left(>30^{\circ} \mathrm{C}\right)$ which reduced the elasticity of dough (Hurkman et al., 2003). Amylopectin was higher in year 1, which was due to changes in the seasonal temperature. However, changes in amylopectin of cultivars associated with their starch composition in grain that responded differently to HTS.

Interaction $(\mathrm{HTS} \times \mathrm{Y})$ showed a higher $(\mathrm{P}<0.05)$ amylopectin in the year 1 for the control and rest of treatments (Figure 4a). It is evident from the literature that temperature differed within years. This resulted in changes for HTS with varying indices. Changes in amylopectin content were observed accordingly with changes in HTS of years (Patindol et al., 2014). The differences in ambient temperature as well as stress index when crop faced HTS at anthesis stage resulted in higher amylopectin content. Interaction $(\mathrm{C} \times \mathrm{HTS})$ reflected an increasing trend in amylopectin of cultivars with increase HTS from control to every next day shock (Figure 4b). The highest amylopectin was observed in P-2. Extending HTS significantly $(\mathrm{P}<0.05)$ reduced the ratio of types " $\mathrm{A}$ " and " $\mathrm{B}$ " starch granules and caused variations in cultivars with HTS and its durations. In literature, the ratio of starch granules (e.g. A-type) was significantly $(\mathrm{P}<0.05)$ increased with increasing HTS at wheat grain development (Beckles and Thitisaksakul, 2013). Interaction $(\mathrm{C} \times \mathrm{Y})$ also showed similar a trend with higher amylopectin in all cultivars for year 1 (Figure 4c). The HTS had negative effects on starch formation in grains and year 1 differed in HTS than the year 2, and hence recorded higher amylopectin for year 2 when the crop was entered in the reproductive stage of growth. Interaction $(\mathrm{C} \times \mathrm{HTS} \times \mathrm{Y})$ also showed a higher amylopectin content for both years with increasing HTS (Figure 4d).

Table 3. Grain gluten and N-content (\%) of selected wheat cultivars affected by high temperature shocks (HTS) with raising temperatures effective from the anthesis stage of growth.

\begin{tabular}{|c|c|c|c|c|c|c|}
\hline \multirow{2}{*}{ Cultivars (C) } & \multicolumn{3}{|c|}{ Grain wet gluten content (\%) } & \multicolumn{3}{|c|}{ Grain nitrogen content $(\%)$} \\
\hline & $2017-18$ & 2018-19 & Mean & $2017-18$ & $2018-19$ & Mean \\
\hline Pirsabak-2005 & 20.80 & 22.41 & $21.61 \pm 0.43^{\mathrm{c}}$ & 2.37 & 2.42 & $2.39 \pm 0.12^{\mathrm{c}}$ \\
\hline Pakhtunkhwa-2015 & 20.22 & 22.51 & $21.37 \pm 0.87^{\mathrm{c}}$ & 2.44 & 2.52 & $2.48 \pm 0.25^{\mathrm{b}}$ \\
\hline Pakistan-2013 & 29.91 & 31.27 & $30.59 \pm 0.36^{b}$ & 2.34 & 2.42 & $2.38 \pm 0.39^{c}$ \\
\hline DN-84 & 32.07 & 33.44 & $32.75 \pm 1.01^{\mathrm{a}}$ & 2.21 & 2.28 & $2.24 \pm 0.29^{d}$ \\
\hline P-2 (Line) & 15.38 & 17.41 & $16.39 \pm 0.54^{\mathrm{f}}$ & 2.47 & 2.58 & $2.52 \pm 0.15^{\mathrm{a}}$ \\
\hline P-12 (Line) & 18.55 & 20.75 & $19.65 \pm 0.23^{\mathrm{d}}$ & 2.48 & 2.57 & $2.52 \pm 0.07^{\mathrm{a}}$ \\
\hline P-18 (Line) & 17.92 & 18.84 & $18.38 \pm 0.35^{\mathrm{e}}$ & 2.50 & 2.58 & $2.54 \pm 0.10^{\mathrm{a}}$ \\
\hline $\operatorname{LSD}(0.05)$ for $\mathrm{C}$ & 0.93 & 1.39 & 0.83 & 0.05 & 0.05 & 0.04 \\
\hline \multicolumn{7}{|c|}{ High temperature shocks (HTS) } \\
\hline Control & 27.89 & 29.11 & $28.50 \pm 0.33^{\mathrm{a}}$ & 2.00 & 2.05 & $2.02 \pm 0.66 \mathrm{a}$ \\
\hline $48 \mathrm{~h}$ & 22.78 & 25.14 & $23.96 \pm 0.49^{b}$ & 2.25 & 2.33 & $2.29 \pm 0.99 b$ \\
\hline $72 \mathrm{~h}$ & 20.37 & 22.29 & $21.33 \pm 0.27^{\mathrm{c}}$ & 2.54 & 2.65 & $2.60 \pm 0.55 \mathrm{c}$ \\
\hline $96 \mathrm{~h}$ & 17.45 & 18.69 & $18.07 \pm 0.27^{\mathrm{d}}$ & 2.81 & 2.90 & $2.86 \pm 0.54 \mathrm{~d}$ \\
\hline $\operatorname{LSD}(0.05)$ for HTS & 0.7 & 1.05 & 0.63 & 0.04 & 0.04 & 0.027 \\
\hline Year mean & $22.12 \pm 0.31$ & $23.81 \pm 0.54$ & $22.96 \pm 0.43$ & $2.40 \pm 0.31$ & $2.48 \pm 0.27$ & $2.44 \pm 0.01$ \\
\hline \multirow{2}{*}{ Source of Variance } & \multicolumn{3}{|c|}{ Grain wet gluten content $(\%)$} & \multicolumn{3}{|c|}{ Grain nitrogen content $(\%)$} \\
\hline & df & MS & F-Value & \multicolumn{2}{|c|}{ MS } & F Value \\
\hline Year $(Y)$ & 1 & 119.25 & 519.26 & \multicolumn{2}{|c|}{0.27} & 39.36 \\
\hline Replications within year & 4 & 0.23 & & \multicolumn{2}{|c|}{0.01} & \\
\hline Heat temperature shock (HTS) & 3 & 816.29 & 389.58 & \multicolumn{2}{|c|}{5.53} & 1426.21 \\
\hline Cultivars (C) & 6 & 933.97 & 445.75 & \multicolumn{2}{|c|}{0.28} & 73.26 \\
\hline $\mathrm{HTS} \times \mathrm{C}$ & 18 & 174.29 & 83.18 & \multicolumn{2}{|c|}{0.08} & 20.38 \\
\hline $\mathrm{Y} \times \mathrm{HTS}$ & 3 & 3.22 & 1.54 & \multicolumn{2}{|c|}{0.01} & 1.55 \\
\hline $\mathrm{Y} \times \mathrm{C}$ & 6 & 1.56 & 0.74 & \multicolumn{2}{|c|}{0.00} & 0.56 \\
\hline $\mathrm{Y} \times \mathrm{HTS} \times \mathrm{C}$ & 18 & 0.88 & 0.42 & \multicolumn{2}{|c|}{0.00} & 0.32 \\
\hline Error & 108 & 2.10 & & \multicolumn{2}{|c|}{0.00} & \\
\hline Total & 167 & \multicolumn{2}{|c|}{$\mathrm{CV}=6.30$} & \multicolumn{3}{|c|}{$\mathrm{CV}=2.55$} \\
\hline
\end{tabular}

Means followed by different letters within a category of treatment are statistically different using the least significant difference (LSD) test; * (P<0.05), $* *(0.01)$ and NS == Non-significant. 

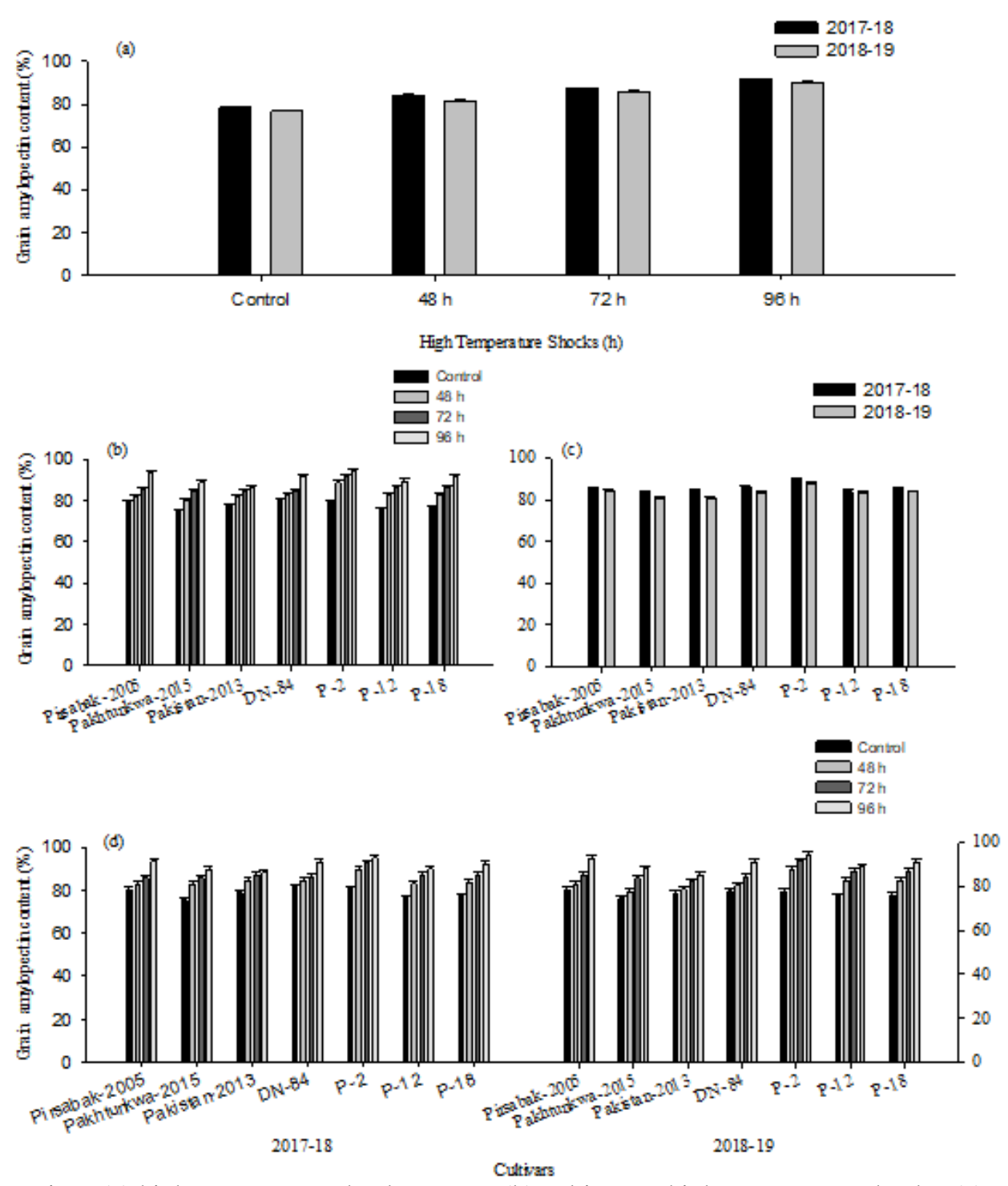

Figure 4. Interactions (a) high temperature shocks $\times$ year, (b) cultivars $\times$ high temperature shocks, (c) cultivars $\times$ years, and $(d)$ cultivars $\times$ heat shock $\times$ years effect on wheat grain amylopectin content $(\%)$ of the selected cultivars exposed to heat shock at anthesis. LSD values of the mean are shown in vertical bars.

Grain development at $\mathrm{HTS}\left(>30^{\circ} \mathrm{C}\right)$ caused significant changes in the composition of starch i.e. dough characteristics which ultimately shows variations in amylopectin (Hurkman et al. 2003). Cultivars responded differently in starch content due to their resistance level at the stage of growth and development to HTS and grain size and its outer layer (Dias et al., 2008) primarily due to the inactivation of key starch synthesizing enzymes (Sharma et al., 2019). Results showed severity index lower in year 1 , resulted in higher amylopectin in wheat grains.

\section{Grain Wet Gluten Content}

Grains wet gluten content (\%) in wheat grains were significantly $(\mathrm{P}<0.05)$ varied for cultivars, HTS and their interaction (Table 3). Two years averages, revealed higher gluten in DN-84, followed by Pakistan-2013. However, the cultivar Pirsabak-2005 was the same in gluten with Pakhtunkhwa-2015 whereas, lowest in P-2. Gluten differences in cultivars are associated with cultivar and environment interaction. Slight changes in temperatures have caused variations in the gluten of same cultivars for the season due to changes in percent N. Gluten in wheat grains are glutenin and gliadin and good backing of the wheat grains associated with a fraction of the glutenin (Laino et al., 2010). Plant subjected to HTS during grain development, glutenin fraction of grain decreased and gliadin increased, which disturbed their ratio and hence has an adverse effect on grain quality (Laino et al., 2010). In this study, a weak dough was the reason for low gluten in cultivars treated with different HTS at anthesis. Gluten showed a consistent reduction with an increase in high temperature shock. Gooding et al. (2003) published that dough strength and sedimentation index reduced in wheat grain subjected to temperature shock $\left(>30^{\circ} \mathrm{C}\right)$ when plant changes from vegetative to reproductive stage. A reduction in dough elasticity was seen when HTS duration extended from control. Differences in gluten between years were also due to changes in HTS for two seasons (Itani et al., 2004). The HTS in year 1 was relatively mild than 2 (Figure $1)$.

Interaction $(\mathrm{C} \times \mathrm{HTS})$ showed diversified responses (Figure 5a). Both Pakistan-2013 and DN-84 showed an increase in gluten content. It was confirmed that the magnitude of change in gluten affects grain flour quality 
(Branlard et al., 2015). Both intensity and duration of the HTS are important to be taken into consideration during grain development to harvest good grain quality. Temperature $30^{\circ} \mathrm{C}$ or above at the anthesis stage of wheat crop and thereafter for grain development is important to be taken into consideration for wheat used for bread regarding protein and gluten (Stone, 2001). It has been also confirmed in literatures that gluten content increased $(\mathrm{P}<0.05)$ when the temperature exceeds $35^{\circ} \mathrm{C}$ during grain development (Stone and Nicolas, 1995). We noticed a considerable increase in gluten at $37^{\circ} \mathrm{C}$ in Pakistan-2013 and DN-84.

\section{Grain Nitrogen Content}

Grain $\mathrm{N}$ content $(\%)$ differed $(\mathrm{P}<0.05)$ for treatments cultivars, HTS and their interaction (Table 3). Higher $\mathrm{N}$ in grain was recorded in $\mathrm{P}-2, \mathrm{P}-12$ and $\mathrm{P}-18$, which were statistically at par $(\mathrm{P}<0.05)$, followed by Pirsabak-2005 and lowest in DN-84. Grain development is mainly influenced by soil and environment during the crop growth; nutrients and water do play a significant role in source-sink assimilate distribution. Imposing HTS at post-anthesis has also adversely affected grain and the grain $\mathrm{N}$ as dilution factor with shrinking grain size and reducing it weight. This has shown a reduction in grain size and an increase in $\mathrm{N}$ content (Asim et al., 2012; Nuttall et al., 2017). Gain N increased with extension in HTS duration from control (i.e. no HTS) also agreed with findings of published literature
(Nuttall et al., 2018). A 6\% higher grain $\mathrm{N}$ observed extending HTS for 4 days, with further extension in HTS duration had increased by $12 \%$ compared to the control (Nuttall et al., 2018). We, therefore, observed differences in grain $\mathrm{N}$ between seasons due to changes in the HTS for years, which could be due to accelerated $\mathrm{N}$ synthesis (Farooq et al., 2011).

Interaction $(\mathrm{C} \times \mathrm{HTS})$ exhibited a similar increasing trend in grain $\mathrm{N}$ for all cultivars with differences for HTS durations (Figure 5b). Cultivars showed an almost similar increase in grain N with HTS except for Pakistan-2013 and DN-84 with a mild change. Cultivars response differed to abiotic stresses, exposed plants to HTS at anthesis showed an increment of grain-N by $+0.03 \%$ per degree rise in the temperature during the early grain growth (Nuttall et al., 2018). It has been proved that slow growth of grain filling at mild temperatures has accumulated more starch and protein, hence having good grains for better backing quality (Farooq et al., 2011). Grain develops at a relatively higher temperature exceeds faster towards maturity and hence has a poor quality of the baked products (Nuttall et al., 2017). It is confirmed through literature that longer grain development duration with optimum temperature has resulted in better yield and higher quality as compared to when plants are subjected to stresses of temperature and/or drought during the reproductive stage of growth (Tomas et al., 2020).
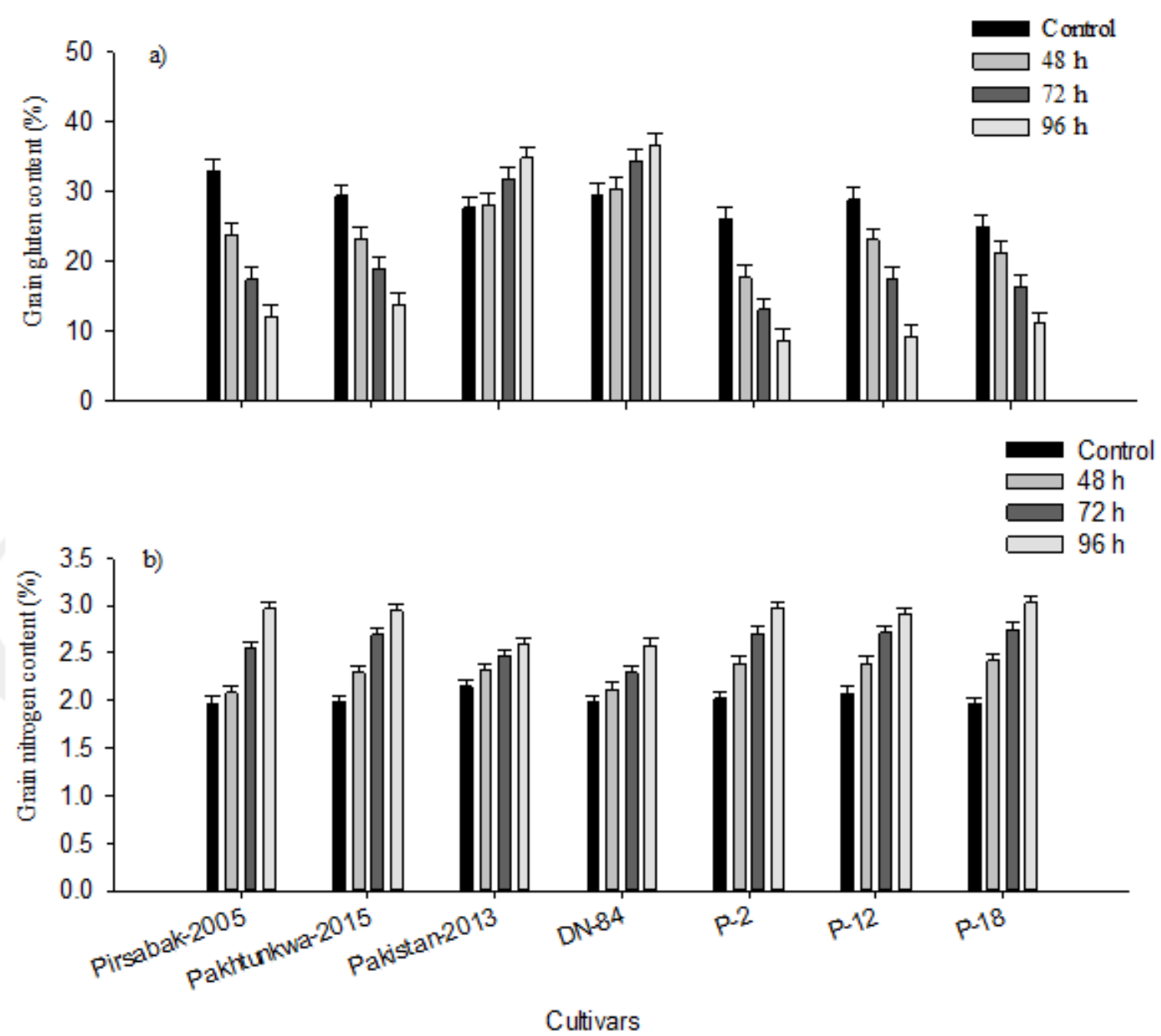

Figure 5. Interactions (a) cultivars $x$ heat shock on grain gluten content, (b) cultivars $\times$ high temperature shocks on grain $\mathrm{N}$-content of wheat cultivars exposed to heat stress at anthesis. LSD values of the mean are shown in vertical bars. 


\section{Conclusions}

Amylose and amylopectin, important constituents of wheat grain for making bread, showed strong sensitivity to high temperature shocks. In addition to year, significant changes were observed for High temperature shock (HTS) and durations on grain quality parameters. Cultivars did differ $(\mathrm{P}<0.05)$ in amylose vs. amylopectin ratios, glutenand nitrogen-content of grains. Nonetheless, the best cultivars selection for a location may wisely address the adverse effects in grain quality of the staple-food e.g. wheat in areas adversely affected by HTS in a changing climate.

\section{Acknowledgements}

The authors highly acknowledged the financial support of the Higher Education Commission, Islamabad in terms of NRPU under the grant 20-5178. The project was on wheat grain $\mathrm{N}$ application and the same facility was also extended for this study. The authors also acknowledged the living expanses support of Inter Cooperation (HelvetasPakistan) to the scholar during her stay at the University.

\section{References}

AACC. 2004. Approved Methods of Analysis, 11th Ed. Method: 38-10.01, American Association of Cereal Chemistry, Am. Assoc. Cereal Chem. Inc., St. Paul, Minnesota. USA.

Abdullah S, Akmal M, Asim M, Abdul R. 2012. Maize growth and yield in Peshawar under changing climate. Pak J Bot, 44:1933-1938.

Anonymous. 2007. Soil Survey of Pakistan.Land resources inventory and agricultural land use plan of Peshawar district. p 102.

Arystanbekkyzy M, Nadeem MA, Aktas H, Yeken MZ, Zencirci N, Nawaz MA, Ali F, Haider MS, Tunc K, Chung G. 2019. Phylogenetic and taxonomic relationship of turkish wild and cultivated emmer (Triticum turgidum ssp. dicoccoides) revealed by iPBSretrotransposons markers. Int J Agric Biol, 21:155-163.

Asim M, Akmal M, Khan A. 2012. Rate of nitrogen application influences yield of maize at low and high population in Khyber Pakhtunkhwa, Pakistan. Pak. J. Bot. 44 (1), 289-296.

Awan KA, Ali J, Akmal M. 2017. Yield comparison of potential wheat varieties by delay sowing as rainfed crop for Peshawar climate. Sarhad J Agric, 33:480-488.

Bajwa AA, Farooq M, Al-Sadi AM, Nawaz A, Jabran K, Siddique KH. 2020. Impact of climate change on biology and management of wheat pests. Crop Prot, 137:105304.

Bala S, Asthir B, Bains N. 2018. Heat and drought stress responses alter grain characteristics by impeding starch precursors of wheat. Indian J Exp Biol, 56:556-572.

Beckles DM, Thitisaksakul M. 2014. How environmental stress affects starch composition and functionality in cereal endosperm. Starch-Starke, 66:58-71.

Branlard G, Lesage VS, Bancel E, Martre P, Meleard B, Rhazi L. 2015. Coping with wheat quality in a changing environment: proteomics evidence for stress caused by environmental changes. In: Ogihara Y, Shigeo T, Hirokazu H, editors. Advances in Wheat Genetics: From Genome to Field. Tokyo: Springer. p 255-264.

Cheng F, Ding Y, Zhu B. 2000. The formation of amylose content in rice grain and its relation with field temperature. Acta Ecol Sin, 20:646-652.

Dias AS, Bagulho AS, Lidon FC. 2008. Ultrastructure and biochemical traits of bread and durum wheat grains under heat stress. Braz J Plant Physiol, 20:323-333.
Fan Y, Ma C, Huang Z, Abid M, Jiang S, Dai T, Zhang W, Ma S, Jiang D, Han X. 2018. Heat priming during early reproductive stages enhances thermo tolerance to post-anthesis heat stress via improving photosynthesis and plant productivity in winter wheat (Triticum aestivum L.). Front Plant Sci, 9:805.

FAO. 2013. Review of the wheat sector and grain storage issues. Food and Agriculture Organization of the United Nations. Rome, Italy.

FAO. 2015. FAOSTAT. Food and agriculture organization of the United Nations. FAO Statistics Division. Rome, Italy

FAO. 2018. FAOSTAT. Food and Agriculture Organization of United Nations. FAO Statistics Division. Rome, Italy.

Farooq M, Bramley H, Palta JA, Siddique KH. 2011. Heat stress in wheat during reproductive and grain filling phases. CRC Crit Rev Plant Sci, 30:491-507.

Giraldo P, Benavente E, Manzano-Agugliaro F, Gimenez E. 2019. Worldwide research trends on wheat and barley: A bibliometric comparative analysis. Agronomy, 9:352.

Gooding M, Ellis R, Shewry P, Schofield J. 2003. Effects of restricted water availability and increased temperature on the grain filling, drying and quality of winter wheat. J Cereal Sci, 37:295-309.

Hanif M, Ali J. 2014. Climate scenarios 2011-2040 districts Haripur, Swabi, Attock and Chakwal Pakistan. Study conducted by Climate Change Centre, University of Agriculture, Peshawar.

Hawker J, Jenner C. 1993. High temperature affects the activity of enzymes in the committed pathway of starch synthesis in developing wheat endosperm. Funct Plant Biol, 20:197-209.

Hurkman WJ, McCue KF, Altenbach SB, Korn A, Tanaka CK, Kothari KM, Johnson EL, Bechtel DB, Wilson JD, Anderson OD. 2003. Effect of temperature on expression of genes encoding enzymes for starch biosynthesis in developing wheat endosperm. Plant Sci, 164:873-881.

IPCC. 2013. The Physical Science Basis. Contribution of working group I to the fifth assessment report of the Intergovernmental Panel on Climate Change New York, USA: Cambridge University Press. 1535 p.

Itani T, Tamaki M, Hayata Y, Fushimi T, Hashizume K. 2004. Variation of 2-acetyl-1-pyrroline concentration in aromatic rice grains collected in the same region in Japan and factors affecting its concentration. Plant Prod Sci, 7:178-183.

Jones Jr J. 1991. Kjeldahl method for nitrogen determination. Athens (GA): Micro-Macro Publishing.

Juliano BO. 1971. Simplified assay for milled rice amylose. Cereal SciToday, 16:334-360.

Khan MIR, Asgher M, Khan NA. 2013. Rising temperature in the changing environment: a serious threat to plants. ESCC, 1:25-36.

Kumar D, Sharma S, Sharma R, Pundir S, Singh VK, Chaturvedi D, Singh B, Kumar S, Sharma S. 2021. Genome-wide association study in hexaploid wheat identifies novel genomic regions associated with resistance to root lesion nematode (Pratylenchus thornei). Sci Rep, 11:1-14.

Laino P, Shelton D, Finnie C, De Leonardis AM, Mastrangelo AM, Svensson B, Lafiandra D, Masci S. 2010. Comparative proteome analysis of metabolic proteins from seeds of durum wheat (cv. Svevo) subjected to heat stress. Proteomics, 10:2359-2368.

Liu B, Liu L, Tian L, Cao W, Zhu Y, Asseng S. 2014. Post heading heat stress and yield impact in winter wheat of China. Glob Change Biol, 20:372-381.

Liu P, Guo W, Jiang Z, Pu H, Feng C, Zhu X, Peng Y, Kuang A, Little C. 2011. Effects of high temperature after anthesis on starch granules in grains of wheat (Triticum aestivum L.). J Agric Sci, 149:159-169.

MINFS\&R. 2018-19. Agricultural Statistics of Pakistan. Ministry of National Food Security and Research, Government of Pakistan, Islamabad. 
Nezhadahmadi A, Prodhan ZH, Faruq G. 2013. Drought tolerance in wheat. Sci World J, 2013:12-32.

Nuttall J, O'leary G, Panozzo J, Walker C, Barlow K, Fitzgerald G. 2017. Models of grain quality in wheat: A review. Field Crops Res, 202:136-145.

Parent B, Turc O, Gibon Y, Stitt M, Tardieu F. 2010. Modelling temperature-compensated physiological rates, based on the coordination of responses to temperature of developmental processes. J Exp Bot, 61:2057-2069.

Patindol JA, Siebenmorgen TJ, Wang YJ, Lanning SB, Counce PA. 2014. Impact of elevated nighttime air temperatures during kernel development on starch properties of field grown rice. Cereal Chem, 91:350-357.

Sangu N. 2018. Quality of grain from crosses between Australian and tetraploid wheat varieties [Master of Philosophy M.Phil]: University of Sydney, Faculty of Science, School of Life and Environmental Sciences.

Schirmer M, Hochstotter A, Jekle M, Arendt E, Becker T. 2013 Physicochemical and morphological characterization of different starches with variable amylose/amylopectin ratio. Food Hydrocoll, 32:52-63.

Sharma D, Singh R, Tiwari R, Kumar R, Gupta VK. 2019. Wheat responses and tolerance to terminal heat stress: a review. In: Mirza H, Kamrun N, Amzad H, editors. Wheat poduction in changing environments. Singapore: Springer. p 149-173.

Soh NL, Touyz SW, Surgenor LJ. 2006. Eating and body image disturbances across cultures: A review. J Eat Disord,, 14:5465.
Steel RGD, Torrie JH, Dickey DA. 1997. Principles and procedures of statistics: a biometrical approach. New York, USA: McGraw-Hill.

Stone P. 2001. The effects of heat stress on cereal yield and quality. In: Amarjit SB, editor. Crop responses and adaptations to temperature stress. New York, USA: The Haworth Press p243-291.

Stone P, Nicolas M. 1995. Effect of timing of heat stress during grain filling on two wheat varieties differing in heat tolerance. I. Grain growth. Funct Plant Biol, 22:927-934.

Tao Z, Chang X, Wang D, Wang Y, Ma S, Yang Y, Zhao G. 2018. Effects of sulfur fertilization and short term high temperature on wheat grain production and wheat flour proteins. Crop J, 6:413-425.

Teixeira EI, Fischer G, Van Velthuizen H, Walter C, Ewert F. 2013. Global hot-spots of heat stress on agricultural crops due to climate change. Agric For Meteorol, 170:206-215.

Tomar S, Singh SK, Sivasamy M. 2014. Wheat rusts in India: resistance breeding and gene deployment-a review. Indian J Genet Plant Breed, 74:129-156.

Tomas D, Rodrigues JC, Viegas W, Silva M. 2020. Assessment of high temperature effects on grain yield and composition in bread wheat commercial varieties. Agronomy, 10:499.

Zhang G, Wang S, You J, Wang Q, Ding Y, Ji Z. 2006. Effect of higher temperature in different filling stages on rice qualities. Acta Agronomica Sinica, 32:283-287. 